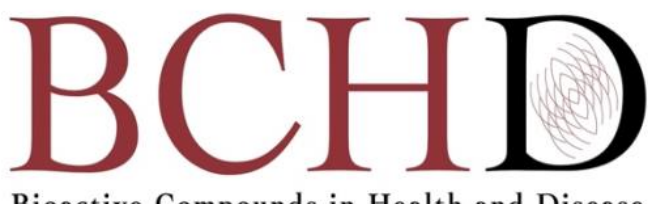

\title{
Phytochemical constituents and biological properties of domesticated capsicum species: a review
}

\author{
Aqsa Akhtar, Waqas Asghar, Nauman Khalid \\ School of Food and Agricultural Sciences, University of Management and Technology, Lahore, Pakistan \\ *Corresponding Author: Nauman Khalid, PhD, School of Food and Agricultural Sciences, University of Management and \\ Technology Lahore, C II Johar Town Lahore, Pakistan
}

Submission Date: August 12 ${ }^{\text {th }}$, 2021; Acceptance Date: September 28 ${ }^{\text {th }}, 2021$; Publication Date: September $30^{\text {th }}, 2021$

Please cite this as: Akhtar A., Asghar W., Khalid N. Phytochemical constituents and biological properties of domesticated capsicum species: a review. Bioactive Compounds in Health and Disease 2021. 4(9): 201-225. DOI: https://www.doi.org/10.31989/bchd.v4i9.837

\begin{abstract}
Pepper (Capsicum spp) is cultivated and consumed in almost every region of the world both as fresh vegetable and dried spice. Capsicum and its different varieties possess many valuable properties which distinguish them from other vegetables and in many food items as a spice for its strong pungent flavor that is produced during the secondary metabolism of the plant.

Capsicum fruit exhibits a multiple color profile due to the presence of carotenoids which can be used as a natural coloring agent and antioxidant. Almost all the parts of the capsicum are considered a rich source of health-related bioactive compounds including polyphenols, flavonoids, and other aromatic compounds. One of the important biological properties of capsicum is its ability to act as antioxidants to reduce oxidative stress leading to the prevention of several degenerative diseases. The functional compounds of capsicum exhibit excellent antimicrobial properties, particularly against gram-positive pathogenic microorganisms. The nutraceutical functionality of phytogenic compounds obtained from capsicum also confirms the anticarcinogenic and cardio-preventive effectiveness. The essential oils from capsicum are also being used as anti-aging substances in cosmetic products.

Accordingly, this article is an attempt to provide an overview of the chemical and functional properties of the bioactive compounds sourced from capsicum and their effective utilization in the medicine, food, agricultural, cosmetic, and textile industries.
\end{abstract}

Keywords: Capsicum, capsaicinoids, capsaicin, carotenoids, pungency 


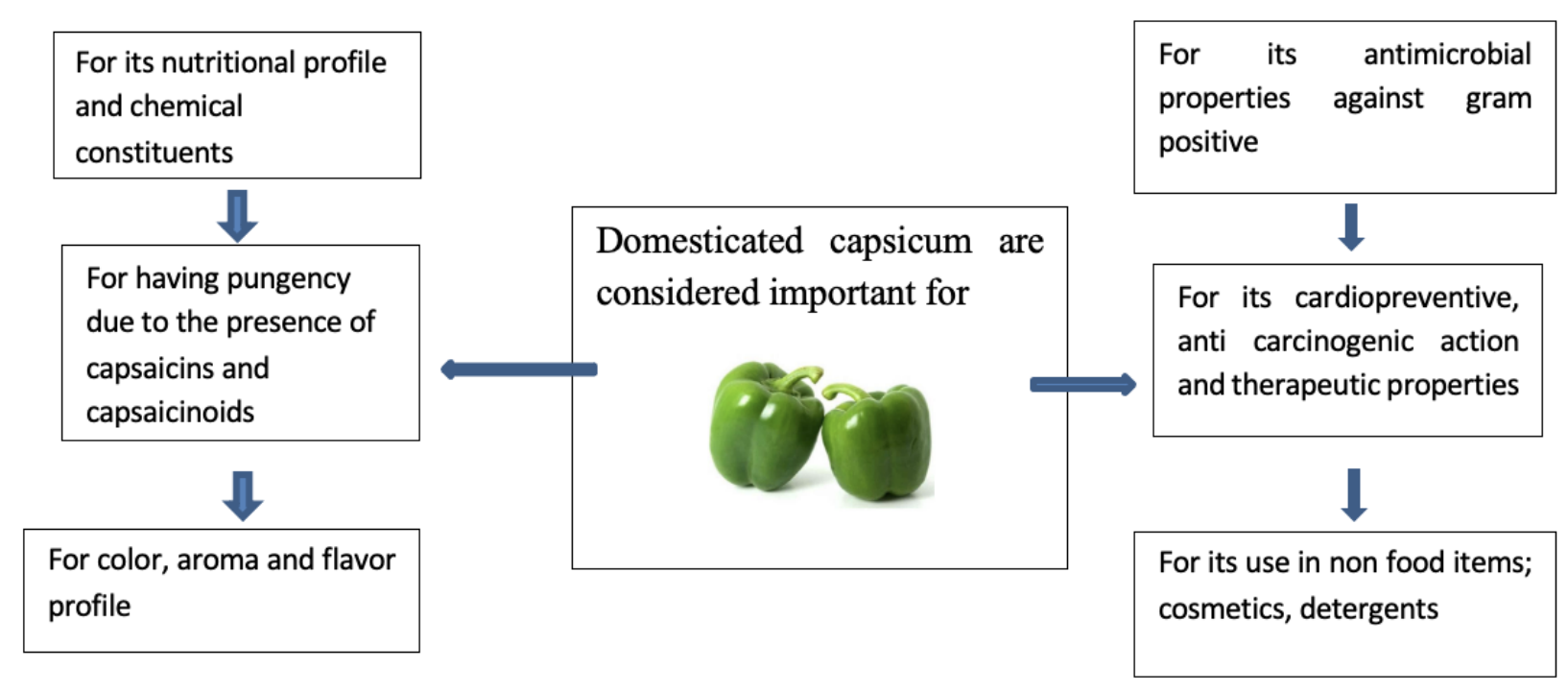

CFFC 2021. This is an Open Access article distributed under the terms of the Creative Commons Attribution 4.0 License (http://creativecommons.org/licenses/by/4.0)

\section{INTRODUCTION}

Capsicum, commonly called pepper, is an annual herbaceous plant and a member of the family Solanaceae. Noted for its pungency, aroma, and color characteristics, Capsicum annuum L. is the most widely grown spice in the world. It is a member of the genus Capsicum that includes close to 30 species and is one of the five domesticated species, others being $C$. baccatum L., C. chinense Jacq., C. frutescens L., and C. pubescens [1, 2]. A native of the Americas, where it has been cultivated for thousands of years, the plant spread to other parts of the world following European colonization and trade activities. C. annuum is also widely cultivated in various tropical, subtropical, as well as temperate regions of the world, and has been a part of the human diet since 7500 $B C$ [2]. The genus is of considerable economic significance as both hot and sweet chili pepper cultivars are cultivated and consumed as both fresh vegetables and as a spice $[3,4]$.
Apart from its use as a culinary commodity, $C$. annuum has also been a subject of pharmacological research due to the presence of various chemical compounds with potential therapeutic properties [4]. The chemical profile, however, varies due to various factors, such as species, seasonality, environmental conditions, as well as the life cycle of the plant [5]. Capsicum has also proved to be very beneficial due to its use in the form of traditional remedies for the cure of various ailments such as ulcers, toothache, rheumatism, alopecia, and diabetes [6]. Capsicum fruit is also unique in chemical composition as it contains phenolic compounds, flavonoids, alkaloids, and carotenoids, that have beneficial effects on human health [7]. Moreover, a host of studies have reported that capsicum seeds are rich in proteins, essential fatty acids, dietary fiber, and minerals, nutritional components highly beneficial for the improvement of human health [8]. Furthermore, various vitamins such as vitamin $C$, vitamin $A$, vitamin $E$, and folate have also been reported in significant amounts 
in C. annuum [9]. The five major domesticated and economically significant capsicum species are presented in Fig 1.

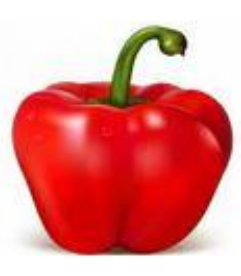

(a)

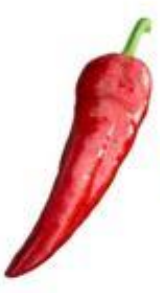

(b)

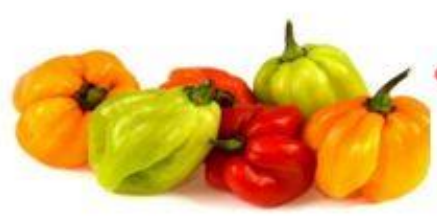

(c)

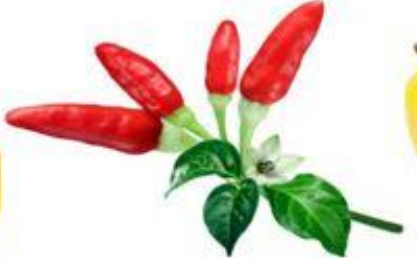

(d)

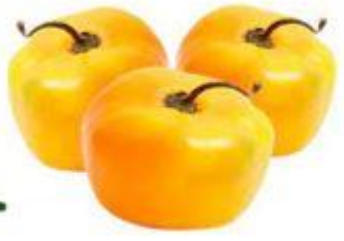

(e)

Figure 1. Capsicum fruits and its major species[28]; a) C. annuum (Sweet bell pepper), b) C. baccatum (aji pepper), c) C. chinense (bhut jolokia pepper), d) C. frutescens (bird's eye chilli), e) C. pubescens (rocoto pepper)

\section{NUTRITIONAL PROFILE AND CHEMICAL COMPOSITION OF CAPSICUM}

C. annuum is a rich source of carbohydrates, with reducing sugars, notably, glucose and fructose predominant over the non-reducing sugars (sucrose) [10]. The dietary fiber content for almost all the $C$. annuum varieties was found to be significant, and it remained consistent through various developmental stages of the plant. A varied amount of protein was reported among different varieties of capsicum. The concentration of proteins was negatively affected by the increased concentration of carbon dioxide $\left(\mathrm{CO}_{2}\right)$ in the atmosphere, whereby an increase in the levels of sugars (both reducing and non-reducing) and fiber was observed by these elevated concentrations of $\mathrm{CO}_{2}[10]$.

Capsicum is also a good source of many water-soluble and fat-soluble vitamins including vitamin B complex, ascorbic acid (vitamin $C$ ), vitamin $A$ and $\beta$-carotenes, as well as a significant amount of minerals including zinc, iron, calcium, potassium, sodium, and sulfur [11]. The detailed proximate composition of $C$. annuum and $C$. chinense is highlighted in Table 1.

Table 1: Chemical composition of the Capsicum annuum and Capsicum chinense

\begin{tabular}{|c|c|c|c|}
\hline Nutrient & $\begin{array}{l}\text { Capsicum annuum } \\
\text { (In } 100 \text { g sample) }\end{array}$ & $\begin{array}{l}\text { Capsicum chinense } \\
\text { (In } 100 \mathrm{~g} \text { of sample) }\end{array}$ & References \\
\hline Water & $8.2 \mathrm{~g}$ & $8.43 \mathrm{~g}$ & {$[11,12,73]$} \\
\hline Energy & 5.724 Kcal & - & {$[11,12]$} \\
\hline Carbohydrate & $47.23 \mathrm{~g}$ & $50 \mathrm{~g}$ & {$[11,12,73]$} \\
\hline Fiber, total dietary & $33.17 \mathrm{~g}$ & $29.26 \mathrm{~g}$ & {$[11,12,73]$} \\
\hline Protein & $11.22 \mathrm{~g}$ & $8.2 \mathrm{~g}$ & {$[11,12,73]$} \\
\hline Total lipid (Fat) & $2.1 \mathrm{~g}$ & $5.06 \mathrm{~g}$ & {$[11,12,73]$} \\
\hline Saturated fatty acids & $0.059 \mathrm{~g}$ & - & {$[11,12]$} \\
\hline $\begin{array}{l}\text { Monounsaturated fatty acids } \\
\text { (MUFA) }\end{array}$ & $0.050 \mathrm{~g}$ & - & {$[11,12]$} \\
\hline Total ash content & $6.26 \mathrm{~g}$ & $7.33 \mathrm{~g}$ & {$[11,12,73]$} \\
\hline
\end{tabular}




\begin{tabular}{|llll|}
\hline Nutrient & $\begin{array}{l}\text { Capsicum annuum } \\
\text { (In } 100 \mathrm{~g} \text { sample) }\end{array}$ & $\begin{array}{l}\text { Capsicum chinense } \\
\text { (In 100 g of sample) }\end{array}$ & References \\
\hline Calcium (Ca) & $80.16 \mathrm{mg}$ & $60.12 \mathrm{mg}$ & {$[11,12,73]$} \\
\hline Iron (Fe) & $7.73 \mathrm{mg}$ & $4.12 \mathrm{mg}$ & {$[11,12,73]$} \\
\hline Sodium (Na) & $22 \mathrm{mg}$ & $36 \mathrm{mg}$ & {$[11,12,73]$} \\
\hline Cupper (Cu) & $0.007 \mathrm{mg}$ & - & {$[11,12]$} \\
\hline Phosphorous (P) & $5.274 \mathrm{mg}$ & - & {$[11,12]$} \\
\hline Selenium (Se) & $0.158 \mathrm{mcg}$ & - & {$[11,12]$} \\
\hline Manganese (Mn) & $0.036 \mathrm{mg}$ & - & {$[11,12]$} \\
\hline Magnesium (Mg) & $2.736 \mathrm{mg}$ & - & {$[11,12,73]$} \\
\hline Zinc (Zn) & $15.78 \mathrm{mg}$ & $39.64 \mathrm{mg}$ & {$[11,12,73]$} \\
\hline Potassium (K) & $6925 \mathrm{mg}$ & $5041 \mathrm{mg}$ & {$[11,12]$} \\
\hline Thiamin (Vitamin B1) & $0.006 \mathrm{mg}$ & - & {$[11,12]$} \\
\hline Riboflavin (Vitamin B2) & $0.017 \mathrm{mg}$ & - & {$[11,12]$} \\
\hline Niacin (Vitamin B3) & $0.157 \mathrm{mg}$ & - & {$[11,12]$} \\
\hline Vitamin B6 & $0.037 \mathrm{mg}$ & - & {$[11,12]$} \\
\hline Ascorbic acid (Vitamin C) & $1.375 \mathrm{mg}$ & - & \\
\hline
\end{tabular}

Almost all the varieties of capsicum (green, sweet, and hot) are rich in important phytochemicals such as flavonoids and polyphenols that can be regarded as bioactive food ingredients. Other phytochemicals present in capsicum include glycosides and aglycones such as quercetin, myricetin, luteolin, kaempferol, and apigenin [12]. Whereas, glycosides are naturally present in plants' secondary metabolites and are catalyzed by the glycosyltransferase enzymes. Glycosides are composed of two functionally independent parts aglycone and glycone (sugar moiety) which are weakly linked together by glycosidic linkage. These glycosidic linkages can be of different types such as O-glycosides (if the glycosidic linkage formed via oxygen) most abundant plants glycosides, C-glycosides (if the glycosidic bond is with carbon), this linkage is most resistant to hydrolysis [13].
Many studies have been conducted for the identification of carbon and oxygen glycosides using techniques including mass spectrometry fragmentation, and ultraviolet spectral analysis. The results of these studies indicate the presence of four different types of quercetin (30-rhamnoside,3-O-rhamnoside-7-0glucoside, 3-0-glucoside-7-O-rhamnoside, and quercetin glycosylated), two luteolin $O$-glycosides (apiosyl-acetylglucoside and 7-O-2-apiosyl-glucoside), five luteolin-Cglycosides (6-C-hexoside, 8-C-hexoside, 6-C-pentoxide-8C-hexoside, 6-C-hexoside-8-C-pentoside, and 6-8-di-Chexoside), and two apigenin C-glycosides (6-C-pentoside8-C-hexoside and 6-8-di-C-hexoside) in capsicum [14-16].

The amount of different bioactive compounds in capsicum fruits varies according to the species, genetic properties, growth, and developmental stages, as well as ecological conditions. The red color fruits of capsicum 
cultivars exhibit the highest level of bioactive compounds, among all the fruits of this family and green color fruits are rich in quercetin 3-O-R-Lrhamnopyranoside which concentration get down during the process of ripening.

However, in the case of capsicum, the bioactive compounds are present in significantly adequate levels and are responsible for many cellular and physiological

\section{PUNGENCY - A CHARACTERISTIC TRAIT OF CAPSICUM}

Pungency ('heat') is the prime characteristic of almost all the capsicum varieties and can be attributed to the wider appeal of the plant's utilization as a spice. The two genes that have been discovered to be the determinative factors for the production of pungency in capsicum are Pun1 and pAMT [18]. This appealing property of pungency develops in the capsicum plants during the secondary metabolism when plants produce various beneficial chemicals for humans by way of either of the two pathways, i.e. the phenylpropanoid, and the branched-chain fatty acid pathways [19]. The class of alkaloids that are biosynthesized and ultimately accumulate in the placental tissue during secondary metabolism in capsicum is capsaicinoids and are the principal components responsible for the pungency in chili peppers. The major representative groups of capsaicinoids involved in pungency are capsaicin and dihydrocapsaicin [20].

Capsaicin(trans-8-methyl-N-vanillyl-6nonenamide), a HVA derivative, is a hydrophobic, colorless, and odorless compound, and can act as a deterrent against herbivores, and microbial and fungal attacks [21]. Large concentrations of capsaicin are present in placental tissue (where the seeds attach), inner membranes, while to a lesser extent, in the fleshy parts of the fruit [22]. The minor capsaicinoids found in chili fruits include activities [12]. Some species of red and purple capsicum also contain anthocyanin andthe major anthocyanin present in these fruits is delphinidin-3-transcoumaroylrutinoside5-glucoside, whereas, the total anthocyanin amount present in fruits ranges between 0.5

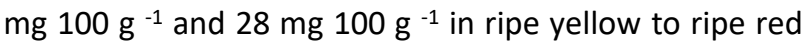
fruit respectively [17].

nordihydrocapsaicin (7.4\%), norcapsaicin, homocapsaicin I, homodihydrocapsaicin I (2\%), homocapsaicin II (2\%), homodihydrocapsaicin II, and nonivamide [23]. The degree of pungency in the Capsicum plant is directly proportional to the concentration of capsaicinoids present, in particular, the capsaicins [4, 23]. An alteration in the acid portion of the capsaicin has been associated with the production of analogs with varying degrees of pungency in capsicum fruits [7].

Among the domesticated species of the genus capsicum, the fruit of $C$. chinense is regarded as the most pungent [7]. The level of pungency in hot pepper can be determined by using the (SHV), which acts as an indicator of the number of capsaicinoids present in the sample (the higher the SHV value, the higher will be the pungency of the pepper). In this test, the sample of hot peppers was presented to the panel of 5 trained people. These people record the hot flavor intensity of the provided chili sample. The provided chili sample is diluted to the level at which pungency becomes undetectable, and this dilution is expressed as the Scoville Heat Unit (SHU). The study also reported that among all the capsaicinoids, capsaicin and dihydrocapsaicin showed the most burning flavor and both of these capsaicinoids are responsible for $90 \%$ of the total pungency of the capsicum [24].

Capsinoids are the other group of secondary metabolites produced in various species of capsicum, 
albeit, they are the non-pungent analogs of capsaicin, and therefore due to this characteristic, have various medical applications [5]. The three major capsinoids associated with chili pepper fruits include capsiate, dihydrocapsiate, and nordihydrocapsiate, all of which have exhibited anti-oxidative and anti-inflammatory properties [20]. The chemical structures of major bioactive components are highlighted in Figure 2.<smiles>COc1ccc(CNC(=O)CCCC/C=C/C(C)C)cc1O</smiles>

Figure 2a. Structure of capsaicin $\left(\mathrm{C}_{18} \mathrm{H}_{27} \mathrm{NO}_{3}\right)$.<smiles>COc1cc(CNC(=O)CCCCCCC(C)C)ccc1O</smiles>

Figure $\mathbf{2 b}$. Structure of dihydrocapsaicin<smiles>COc1cc(CNC(=O)CCCCCC(C)C)ccc1O</smiles>

Figure 2c. Structure of nordihydrocapsaicin<smiles>O=c1cc(-c2ccc(O)c(O)c2)oc2cc(O)cc(O)c12</smiles>

Figure 2d. Structure of luteolin 
<smiles>CC1=C(/C=C/C(C)=C/C=C/C(C)=C/C=C/C=C(C)/C=C/C=C(C)/C=C/C2=C(C)CCCC2(C)C)C(C)(C)CCC1</smiles>

Figure 2e. Structure of carotenoids<smiles>COc1cc(COC(=O)CCCC/C=C/C(C)C)ccc1O</smiles>

Figure 2f. Structure of capsiate<smiles>CCCCCCCC(=O)OCc1ccc(O)c(OC)c1</smiles>

Figure $\mathbf{2 g}$. Structure of nordihydrocapsiate<smiles>COc1cc(COC(=O)CCCCCCC(C)C)ccc1O</smiles>

Figure $\mathbf{2 h}$. Structure of dihydrocapsiate

\section{Synthesis and accumulation of pungent compounds: The}

synthesis of capsaicinoids takes place in the placental tissues, pericarp, seeds, and other vegetative organs including stems and leaves of the capsicum plant. Most of the capsaicinoids are formed during the initial phases of the fruit development, i.e. about 20 to 50 days after the anthesis, and this rate of synthesis of capsaicinoids increases as the fruit matures [23].
The other factors which also contribute to the production of capsaicinoids include genotype, fruit maturity, as well as environmental factors such as water availability and solar energy [23]. As mentioned earlier, the two pathways by which capsaicinoids are biosynthesized are the phenylpropanoid pathway and the branched-chain fatty acid pathway.

The primary precursor phenylalanine of the phenylpropanoid pathway is condensed with the primary 
precursor, valine (or leucine) of the fatty acid pathway, and produces vanillylamine, which plays a key role in the formation of capsaicinoids, and their eventual accumulation in the placental tissue of the fruit [25].

There are many putative enzymes and codifying genes

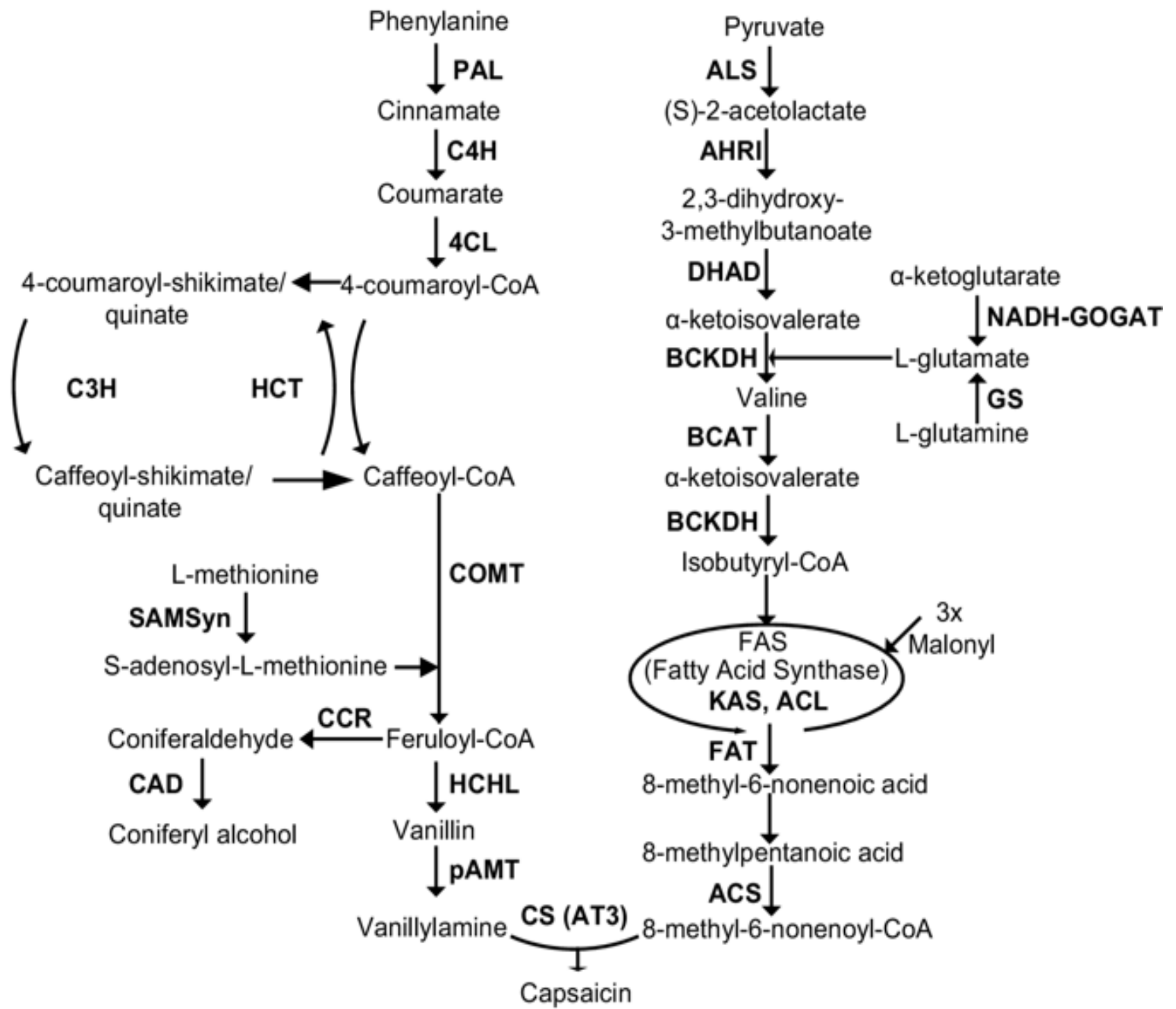

Figure 3. Model pathway of capsaicin (capsaicinoids) biosynthesis in capsicum [25]

COLORING COMPOUNDS OF CAPSICUM: Color is one of the main quality indicators for both fresh pepper fruit, as well as the food products derived from it. There are a total of four genes $\left(y, c_{1}, c_{2}, c l\right)$, and around 20 associated with the biosynthesis of the capsaicinoids, however, their complete characterization has not been achieved yet [25]. The model pathway for capsaicin synthesis is represented in Figure 3.

(S)-2-acetolactate

2,3-dihydroxy-

3-methylbutanoate

a-ketoisovalerate

CKDH

a-ketoisovalerate

BCKDH

Isobutyryl-CoA

8-methyl-6-nonenoic acid

8-methylpentanoic acid

ACs

Capsaicin 
mevalonate) pathway and are mostly stored in the chromoplasts of capsicum fruit. Carotenoids normally have a 40-carbon isoprene structural backbone with the aromatic ring structures at one or both ends of the molecule, and the chemical structure of the carotenoids results from 5-carbon isoprenoid groups with an alternating double bond [27]. The carotenoids are present in varying colors including yellow, orange, and red, ultimately imparting yellow to red coloration in different varieties of Capsicum, and these carotenoids develop and change color as the fruit ripens [28].

At the beginning of the fruit ripening process, the carotenoids chlorophyll ratio present in capsicum fruit has been reported to be 32:68, resulting in chlorophyll imparting green color to the fruits [28]. The major carotenoids responsible for the red color in capsicum are capsanthin and capsorubin, while lutein is responsible for the color in green and yellow varieties. Moreover, yellow to orange color in Capsicum can be attributed to the

AROMA AND FLAVOR PROFILE OF CAPSICUM: The aroma is one of the most important indicators to determine the quality of capsicum and changes according to the variety, ripening stages, and storage method [32]. The characteristic aroma and flavor of fresh capsicum fruits can be attributed to the presence of volatile oils. The first aromatic compound identified in the bell pepper was 3-isobutyl-2-methoxypyrazine, an alkylmethoxypyrazine [33]. Since then, other volatile compounds have also been identified in different cultivars of red chili pepper, such as 2,3-butanedione, which has a certain caramel note, and 1-penten-3-one, also found associated with the pungent and spicy sensation of the Capsicum fruit, hexanal compounds, found to be responsible for herbal favor, 3-carene, a presence of $\beta$-carotenes, cryptoxanthin, zeaxanthin, violaxanthin, antheraxanthin, and cucurbitaxanthin A. These carotenoids have been reported to play important roles in various biological and health activities as well, besides imparting color to capsicum fruit [26, 29].

Capsicum varieties are considered as natural coloring agents in the food industry for coloring of various types of processed foods such as sauces, gravies, condiments, salad dressings, baked goods, and snacks. Other than the food industry, the natural coloring potential of capsicum varieties is also gaining importance in the cosmetic and pharmaceutical industries for both color and nutraceutical functions [30]. Carotenoids have excellent antioxidant properties as well because of the presence of conjugated double bonds which give them the ability to protect cells by scavenging the ROS and formation of free radicals, and therefore, preventing against different degenerative diseases [31].

characteristic compound of red bell pepper, ocimene, $(E)$ 2-hexenal, exhibiting sweetness, and octanal, imparting fruity notes [33].

The abundant aroma compounds reported in all cultivars of capsicum are esters, alcohols, aldehydes, ketones, terpenes, acids, furans, pyrazines, and sulfur compounds [32]. In a study, the volatile compounds have been evaluated in Brazilian $C$. chinense one of the dominant species-genus Capsicum. A total of 82 volatile compounds were detected on analysis and among them, 64 compounds were associated with the aroma of the capsicum. Among these 64 identified compounds, the main class was of esters (51\%), followed by terpenes $(17 \%)$, alkanes $(13 \%)$, alcohols $(9 \%)$, carotenes $(7 \%)$, and fatty acids (3\%) [34]. 
A similar study was conducted in Germany to analyze the flavor profile of the fruits of $C$. baccatum and C. pubescens. Upon analysis, around 200 volatile compounds were detected and among them, 150 volatile compounds were present in fruits of both species. The most abundant compounds were esters and terpenoids, and to a minor extent, nitrogenous compounds, sulfur compounds, phenol derivatives, alcohols, norcarotenoids, furans, ketones, and different hydrocarbons were present. Around 95 ester compounds, saturated esters such as 2-methyl propanoate, 2-methyl butanoate, 3-methyl butanoate, and 4-methylpentanoates, and among unsaturated esters, (Z)- 3-hexenyl 3-methyl butanoate, (Z)-3-hexenyl 4-methyl pentanoate, and 6-methyl-4-heptenyl 3-methyl butanoate were detected. Besides esters, 62 terpenoids were analyzed in volatile fractions of the said fruit and among 62 terpenoids, there were 35 non-oxygenated sesquiterpenes, 18 monoterpenoids, and 9 oxygenated sesquiterpenes [35]. The cultivars of capsicum with red fruits contain a high level of hydrocarbons and help in the biosynthesis of capsaicin and degradation of the carotenoids while the yellow and orange fruits are rich in ester compounds [5]

The worldwide acceptability of the capsicum is due to its flavor, aroma, and pungency. The pungency has a direct association with the level of capsaicinoids present, the greater the level of capsaicinoids that would be bound to the vanilloid receptors in the mouth, the greater will be the burning sensation produced. Among all of the flavor determining components, capsaicinoids contribute the most to the flavor perception attributed to capsicum [36]. According to another study, close to 30 volatile compounds have been identified which impart aroma in three species of Capsicum (annum, chinense, and frutescens) [37].

The fruity aroma of capsicum is also desirable for the utilization of pepper in different food items. The other major capsaicinoids are capsinoids, with a nonpungent characteristic that have an ester bond derived from vanillyl alcohol and fatty acid, and are classified as capsiate, dihydrocapsiate, and nordihydrocapsiate [38]. The consumption of capsinoids surpass the level of capsaicinoids in the body and offsets the level of pungency. Among all the cultivars of capsicum, $C$. chinense cultivars show a high level of pungency with a strong aroma profile [38].

BIOLOGICAL PROPERTIES OF CAPSICUM: The fruit of the capsicum plant has been used for centuries, both as fresh vegetables and a food additive in dried form. However, it has also found applications in traditional medicine to cure cough, toothache, sore throat, parasitic infections of the body, rheumatism, and wound healing [39]. Moreover, it is also used as a treatment to cure common problems including high cholesterol, high blood pressure, joint pains, and skin rashes, as well as a carminative, appetizer, in beverages, relief of neuropathy pain, and as a counter-irritant in the treatment of lumbago [40]. Some other research studies report that it acts as an antioxidant, immune modulator, helps in stimulating the gastrointestinal defense system, and salivary secretions, as well as intestinal, hepatic, and pancreatic secretions $[41,42]$. The results of a study reported that the leaves of three cultivars; Blackcuban (BCPL), Hongjinju (HPL), and Yeokgang-hongjanggun (YHPL) of red pepper plants have high antioxidative properties [43]. The health-related studies associated with Capsicum are highlighted in Table 2. 
Table 2: Health associated role of capsicum and its bio components

\begin{tabular}{|c|c|c|c|}
\hline Health disorder & $\begin{array}{l}\text { Bioactive } \\
\text { compound }\end{array}$ & Mechanism & Reference \\
\hline \multirow[t]{8}{*}{ Anticancer } & Capsaicin & $\begin{array}{l}\text { - Helps to persuade cell cycle detention at } \\
\text { G0/G1 phase }\end{array}$ & [74] \\
\hline & $\begin{array}{l}\text { Capsaicin } \\
\text { Resveratrol }\end{array}$ & - Enhanced $\mathrm{FOXO}_{3}$ a expression & [75] \\
\hline & Capsaicin & - Altered histone acetylation & [76] \\
\hline & Capsaicin & $\begin{array}{l}\text { - } \quad \text { Prevent the growth of colon cancer cells } \\
\text { - Help to lower the formation and secretion of IL-1 } \beta \text {, } \\
\text { TNF- } \alpha, \text { IL-10, IFN- }- \text {, and IL-1ra }\end{array}$ & [77] \\
\hline & Capsaicin & $\begin{array}{l}\text { - Help to induce the secretion of IFN- } \gamma \\
\text { - Stimulate the apoptosis, and reduce the TNOX } \\
\text { activity }\end{array}$ & {$[55]$} \\
\hline & Capsaicin & $\begin{array}{l}\text { - Inhibit the activation of ERK } \\
\text { - Help to reduce the paxillin and FAK } \\
\text { phosphorylation }\end{array}$ & [56] \\
\hline & Capsaicin & $\begin{array}{l}\text { - Increase the regulation of Dhh/Ptch2/Zeb2 } \\
\text { members of the Hedgehog signaling pathway, } \\
\text { Help to improve CD24, VEGFA and TIMP1 and } \\
\text { lower CD44 and ALCAM mRNA gene expressions }\end{array}$ & [78] \\
\hline & Capsaicin & - $\quad$ Reduced the proliferation of renal carcinoma cells & [79] \\
\hline Anticancer & $\begin{array}{l}\text { Capsaicin } \\
\text { Sulforaphane } \\
\text { Resveratrol } \\
\text { Piceatannol }\end{array}$ & $\begin{array}{l}\text { - Pancreatic adenocarcinoma, highly resistant to all } \\
\text { current anti-cancer treatments but combined } \\
\text { actions of several BFCs } \\
\text { - } \quad \text { Provide specific lethal effect towards tumor cells } \\
\text { - BFCs enhanced fibrotic response as compared to } \\
\text { gemcitabine treatment alone. } \\
\text { (ROS) and apoptosis increases while the cell cycle } \\
\text { was very slightly affected }\end{array}$ & [75] \\
\hline Anti-cancer & Capsazpine & $\begin{array}{l}\text { - } \quad \text { Capsazepine is a synthetic analog of capsaicin } \\
\text { - Show anti-proliferative effects in human prostate } \\
\text { cancer cells } \\
\text { - Help to reduce the multiplication of tumor cells }\end{array}$ & [10] \\
\hline Cardiovascular & Dietary capsaicin & $\begin{array}{l}\text { - Lowers the level of triglycerides, total cholesterol } \\
\text { content and low-density lipoprotein } \\
\text { - In plasma help to stimulate cholesterol } 7 \alpha \text { - } \\
\text { hydroxylase enzyme expression to prevent } \\
\text { cardiovascular disorders }\end{array}$ & [80] \\
\hline Cardio-preventive & Dihydrocapsaicin & $\begin{array}{l}\text { - Cellular cholesterol decreased } \\
\text { - Cholesterol efflux increased when cells were treated } \\
\text { with dihydrocapsaicin }\end{array}$ & [81] \\
\hline Antidiabetic & Capsaicin & $\begin{array}{l}\text { - Facilitate the full activation of TRPV1- } \\
\text { expressing neurons hyperglycemia perspective } \\
\text { to lower the blood glucose }\end{array}$ & {$[82,83]$} \\
\hline
\end{tabular}




\begin{tabular}{|c|c|c|c|}
\hline & Capsaicin & $\begin{array}{l}\text { - } \quad \text { Reduces mitochondrial } \mathrm{Bcl}-2 \text { protein production } \\
\text { - } \quad \text { Increased cytochrome c levels to cure diabetes }\end{array}$ & [84] \\
\hline & Capsaicin & $\begin{array}{l}\text { - } \text { Reduced the number of store lipids and glucose } \\
\text { - Enhance adiponectin gene expression and its } \\
\text { receptor (AdipoR2) expression for activation } \\
\text { - } \quad \text { Activated hepatic AMP-activated protein kinase }\end{array}$ & [85] \\
\hline \multirow[t]{4}{*}{ Anti-obesity } & Capsaicin & $\begin{array}{l}\text { - Improved bone morphogenetic protein-8b and } \\
\text { brown fat specific thermos-genic uncoupling } \\
\text { protein-1 expression to reduce obesity } \\
\text { - Triggered browning of white adipose tissue }\end{array}$ & [86] \\
\hline & Capsaicin & $\begin{array}{l}\text { - Repressed initiation of adipocytic differentiation, } \\
\text { lipogenesis, and maturation } \\
\text { Repressed PPARy, C/EBP } \alpha, \text { FABP4, and SCD-1 gene } \\
\text { expression }\end{array}$ & [87] \\
\hline & Capsaicin & $\begin{array}{l}\text { - Inhibited fat accumulation and a significant } \\
\text { decrease in HMGCoA reductase, CPT-1, FAT/CD36 } \\
\text { and GLUT4 levels }\end{array}$ & [59] \\
\hline & $\begin{array}{l}\text { Capsaicin } \\
\text { Curcumin }\end{array}$ & $\begin{array}{l}\text { - Lowers the levels of malondialdehyde (aldehyde } \\
\text { associated with lipid oxidation) and } \\
\text { phosphatidylcholine hydro-peroxide levels } \\
\text { - Enhanced the concentrations of catalase and } \\
\text { superoxide dismutase activity }\end{array}$ & [88] \\
\hline Antiaging & Capsaicin & $\begin{array}{l}\text { - Decreased the KA-facilitated rise in cytokines IL-1 } \\
\text { level and TNF- } \alpha \text { declined apoptotic cell death to } \\
\text { reduce the expression of genes }\end{array}$ & [89] \\
\hline \multirow[t]{2}{*}{ Anti-inflammatory } & \multirow[t]{2}{*}{ Dietary Capsaicin } & - $\quad$ Reduced the production of reactive oxygen species & {$[80,90]$} \\
\hline & & $\begin{array}{l}\text { - Prevent the EC-LPS-induced activation of the MAPK } \\
\text { pathway }\end{array}$ & [91] \\
\hline Anti-angiogenic activity & $\begin{array}{l}\text { Lipophilic } \\
\text { antimicrobial } \\
\text { peptides isolated } \\
\text { from paprika leaf }\end{array}$ & $\begin{array}{l}\text { - The antimicrobial peptides help to inhibit the } \\
\text { proliferation of human umbilical vein endothelial } \\
\text { cells } \\
\text { - Suppressed characteristics of angiogenesis } \\
\text { - Used for the treatment of hyper-vascularized } \\
\text { tumors }\end{array}$ & [92]. \\
\hline Anti-obesity & Capsaicin & $\begin{array}{l}\text { - Prevent fat accumulation in visceral and } \\
\text { subcutaneous sites of the body } \\
\text { - Capsaicin activates the receptor vanilloid I channel } \\
\text { and prevent the adipogenesis } \\
\text { - Induce apoptosis in adipocytes and pre-adipocytes } \\
\text { to prevent adipogenesis }\end{array}$ & [93] \\
\hline Memory enhancer & Green chili & $\begin{array}{l}\text { - Help in the improvement of memory in } \\
\text { exteroceptive models } \\
\text { - } \quad \text { Reversal of memory deficits } \\
\text { - } \quad \text { Inhibition of AChE enzyme } \\
\text { - } \quad \text { Cause a significant rise in the levels of glutathione } \\
\text { levels in the brains }\end{array}$ & [94] \\
\hline Healing of gastric ulcers & Red pepper & $\begin{array}{l}\text { - Helps inhibition of acid secretion } \\
\text { - Promote the flow of alkali and gastric mucosal } \\
\text { secretion }\end{array}$ & {$[22]$} \\
\hline
\end{tabular}


Antioxidant activity of capsicum: Antioxidants have been constituents of great interest to researchers for many years now owing to their health-promoting capabilities. Their wide applications in different food items, nutraceutical products, and even cosmetics are well documented, and present an excellent prospect for food processors to extract and quantify them from different foods. Capsicum fruits are a rich source of different phytochemicals such as vitamins $A$ and $C$, flavonoids, and carotenoids. According to the research studies, more than 125 volatile compounds have been identified in fresh and processed Capsicum fruits of Pakistan's bell pepper. However, their significance for aroma profile is not well reported yet [44].

The phenolic compounds tend to inhibit lipid autoxidation by acting as radical scavengers and, consequently, are essential antioxidants that protect against the propagation of oxidative stress. Research studies indicate that hotter varieties of Capsicum contain more phenolic compounds as compared to the sweeter ones [45]. There are some varieties of $C$. annuum including Jalapeño and Serrano that are considered as a good source of ascorbic acid and phenols both fresh and in their processed forms [45]. The main compounds found in the red pepper with significant antioxidant activity levels are sinapoyl and feruloyl glycosides such as trans-p-feruloyl- $\beta$ - $d$-glucopyranoside, trans-p-sinapoyl$\beta$-d-glucopyranoside,trans-p-ferulyl-alcohol-4-0-[6-(2methyl-3-hydroxy-propionyl] glucopyranoside, luteolin and quercetin glycosides [46].

Antimicrobial activity of capsicum: The polyphenolic compounds present in the capsicum have exhibited excellent antimicrobial activity against both beneficial and pathogenic microbial strains. The test microorganisms used for the determination of antimicrobial sensitivity testing included standard strains of gram-positive and gram-negative bacteria Listeria monocytogenes ATCC 7644, Staphylococcus aureus ATCC 6538, Pseudomonas aeruginosa ATCC 27853, Proteus mirabilis ATCC 13315, Escherichia coli ATCC 10536, Salmonella enterica serovar Typhimurium ATCC 13311, Bacillus subtilis ATCC 6633, Bifidobacterium animalis sub sp. lactis Bb12, Lactobacillus acidophilus CECT 4529, Lactobacillus Plantarum CECT 748, and six wild-type strains of $S$. aureus $(8,14,26,32,550,319)$ [47]. $C$. annuum ethanol extracts exhibited significant activity against many bacterial and fungal organisms such as $L$. monocytogenes and Aspergillus flavus in terms of inhibiting their growth [48].

A study by [49] reported that the methanolic extract from the red pepper was tested and found effective against the drug-resistant Vibrio cholerae strains. Another study reported that $\mathrm{n}$-hexane and chloroform extracts from the seeds of $C$. frutescens proved highly effective against many pathogenic microbes including Pseudomonas aeruginosa, Klebsiella pneumonia, Staphylococcus aureus, Candida albicans, Candida krusei, Alternaria alternata and Aspergillus niger [50]. In another study [51], the antimicrobial activity of the acetone and acetonitrile extracts from different parts of the $C$. chinense was reported. The results of the study indicated that both the callus and fruiting body of the $C$. chinense showed higher inhibition activity against the pathogenic E. coli, K. pneumoniae, Salmonella typhi, S. aureus, Streptococcus pyogenes, Bacillus cereus, Aspergillus flavus, and C. albicans. A recent study [52] investigated the antimicrobial potential of the different solvent extracts including methanol, $\mathrm{n}$-hexane, $\mathrm{n}$-butanol, and ethyl acetate from the leaves and fruits of the $C$. annuum. 
The results indicated that the solvent extracts involving butanol and ethyl acetate from both leaves and fruits of Capsicum showed significant inhibition of growth against many pathogenic microorganisms. The growth of E. coli was found highly resistant to organic extracts obtained from the leaves of the plant, while $K$. pneumoniae was found highly resistant to $\mathrm{n}$-hexane extract from leaves. The growth of $P$. aeruginosa and $S$. aureus was found inhibited by all the solvents from the parts of the fruit of the plant. The growth of C. albicans was effectively reduced by ethyl acetate extracted from the leaves of the capsicum.

Antitumor properties of capsicum: Capsaicin has garnered significant interest in terms of its utilization for various medical applications. It has been found effective and has exhibited protective properties against many mutagenic and tumor-causing cells, in particular, by way of inducing apoptosis in these cells. This action of capsaicin, in turn, occurs due to the activity of the tumorassociated NADH-oxidase (tNOX) enzyme which aids in enhancing the cellular growth near the plasma membranes [53]. Chili peppers are rich in $\beta$-carotenes, compounds with antimutagenic and anticarcinogenic properties. The research indicated that the genotoxic activity of urethane in yeast cells, bacteria, and mammal cells was reduced through the use of the red pepper extract. The results indicated that capsaicinoids and carotenoids exhibit considerable anti-mutagenic activity [54].

The mechanism associated with the activity of capsaicinoids is thought to be the $i$ (ICD), a phenomenon that involves the early surface exposure to calreticulin (CRT), a multifunctional chaperone protein. During an investigation, cisplatin (a chemotherapy medication), and capsaicin compounds were found to induce ICD owing to the increased CRT expression, thereby enhancing the cell apoptosis in the human osteosarcoma cells (OCs) MG-63. The treatment with capsaicin, in particular, has been associated with the translocation of calreticulin from the intracellular surfaces to the outer cell surface, helping to increase the phagocytosis of the MG-63 cells, as well as the stimulation of interferongamma (IFN- $\gamma$ ) secretion.

This, consequently, induced apoptosis, which ultimately decreased the growth of the bladder cancer cells by way of inhibition of the activity of the tNOX enzyme, and the protein sirtuin 1 (SIRT1). Furthermore, it was discovered that capsaicin effectively lowered the expression and activity of many proteins associated with the cell cycle progression, thereby reducing the rates of proliferation and migration of the cancer cells $[55,56]$. The most of the data presented in literature showed that administration of low doses of capsaicin suppress the growth of many human cancers and high doses of capsaicin to treat the cancers promotes the growth of the tumor cells [57].

Antidiabetic role of capsicum: The alkaloids present in Capsicum have proven effective in regulating the blood glucose levels, and therefore, have the potential to be used as antidiabetics for humans. A study showed that the crude extract of capsicum fruit helped in inhibiting the intestinal absorption of glucose and probably contributed to lowering the blood sugar level [4]. GDM poses a major health risk for pregnant women as well as their newborns in the future. A study was conducted in which 42 women were provided with capsaicin supplements ( $5 \mathrm{mg} /$ day) at 22-33 gestational weeks. The 
results of the study indicated that chili supplements including capsaicin improved postprandial

hyperglycemia and hyperinsulinemia as well as fasting lipid metabolic disorders in women with GDM, as well as significantly reducing the incidence of large-forgestational-age (LGA) newborns [58].

Another study [59] conducted to determine the effect of DHC in mice reported positive and beneficial effects of the capsaicinoids. Apolipoprotein M (apoM), a novel lipoprotein-associated plasma protein found in the kidney and liver, is linked with the causation of diabetes mellitus and problems associated with atherosclerosis. The liver hepatocellular (HepG2) cells were treated with different concentrations of dihydrocapsaicin i.e., 0, 25, 50 , and $100 \mu \mathrm{M}$ for 24 hours and the results showed that dihydrocapsaicin efficiently reduced the apoM expression at both protein and mRNA levels in HepG2 cells in a dose- and time-dependent manner. Furthermore, the induction of dihydrocapsaicin significantly lowered atherosclerotic plaque development in $\mathrm{apoE}^{-/}$mice. The dihydrocapsaicin application also negatively impacted the foxhead box protein a2 (Foxa2) expression, although, had a positive effect on the liver $X$ receptor $\alpha(L X R \alpha)$ expression in HepG2 cells.

Cardiovascular role of capsicum: Capsaicinoids such as dihydrocapsaicin have also been reported to reduce the levels of plasma cholesterol, low-density lipoprotein cholesterol (LDL-C), very low-density lipoprotein cholesterol (VLDL-C) as well as triglycerides (TG), and inflammatory cytokines such as interleukin 1 beta (IL-1ß), IL-6, tumor necrosis factor-alpha (TNF- $\alpha$ ), and C-reactive protein (CRP). Moreover, there was a marked increase in the plasma levels of the high-density lipoprotein cholesterol (HDL-C), and Apolipoprotein A1 (apoA1). The plasma sterol analysis further confirmed the findings that capsaicinoids reduced cholesterol absorption by lowering plasma cholesterol levels. Dihydrocapsaicin, owing to its contribution to increased HDL levels, thus actively enhanced the reverse cholesterol transport (CRT) pathway, ultimately leading to suppressed atherosclerosis plaque formation, thereby also promoting cholesterol efflux in THP-1 macrophagederived foam cells [60].

Metabolic syndrome, characterized by a coexistence of high blood glucose levels, obesity, dyslipidemia, and hypertension, is commonly regarded as a major risk factor for the development of CVDs, and consequent mortality. Various studies, both in vivo and in vitro, have been reported regarding the role of capsaicin in reducing obesity, lowering the blood glucose levels, and preventing hyperglycemic episodes, as well as blood cholesterol levels, and decreasing the incidence and prevalence of atherosclerosis. The results of the studies indicated that capsaicin exhibited an anti-hyperlipidemic effect by reducing the intestinal absorption of cholesterol. Another factor related to this effect could also be the activation of peroxisome proliferatoractivated receptor $\alpha$ (PPAR $\alpha)$. This beneficial antidiabetic, antihypertensive, and anti-obesity effect attributed to capsaicins makes them ideal for their use in the treatment of metabolic syndrome and has the potential to significantly decrease the risk of mortality from cardiovascular diseases [61].

Anti-inflammatory activity of capsicum: Inflammation is a biological defense response triggered by a host of factors such as infection, injury, and toxic compounds (Chen et al., 2018), and is a pathological condition if 
sustained. Several studies have reported the antiinflammatory activity of bioactive compounds sourced from Capsicum, including polyphenols, flavonoids, tocopherols, capsaicinoids, and capsinoids $[62,63]$. The anti-inflammatory property of the capsicum is mediated by the inhibition of the (LOX). Different varieties of capsicum demonstrated varying degrees of lipoxygenase inhibition with green capsicum recording the highest (46.12\%), followed by the yellow (44.09\%), and the red capsicum (32.18\%) varieties [64].

The anti-inflammatory properties of capsaicin's are well documented, and they are widely used in topical gel and cream formulations for pain relief. Capsaicin's release the pro-inflammatory mediators, which in turn, activate the TRPV1 (transient receptor potential cation channel subfamily $V$ member 1 , also termed as capsaicin receptors) channels associated with thermoreception and nociception, thereby inducing the inflammation response (Bujak et al., 2019; Lu et al., 2020). An investigation to evaluate the anti-inflammatory effect in murine peritoneal macrophages produced by LPS reported that capsaicin suppressed the production of prostaglandin E2 (PGE2) hormone by inhibiting the activity of the cyclooxygenase-2 (COX-2) enzyme, and the expression of inducible nitric oxide synthase (iNOS). Given that prostaglandins, COX-2, and iNOS are key proinflammatory mediators, the use of capsaicin ultimately contributed to a reduction in inflammation (Lu et al., 2020).

Analgesic effect of capsicum: The extracts from various species of capsicum have been investigated for analgesic effects, linking the compound with nociceptive behaviors. There is a considerable body of work in support of the findings that capsaicin can modulate analgesia by acting at the VR resulting in inhibition of substance $P(S P)$, a neuropeptide that acts as a neurotransmitter and a neuromodulator (Davis et al., 2000). In this regard, capsaicin is particularly effective in lowering the pain associated with painful diabetic neuropathy (PDN), and herpetic and trigeminal neuralgia.

A study by reported in [64]involved the testing of the extract from $C$. frutescens and capsaicin for their effects on peripheral and central components of pain. The results indicated that capsaicin has significant analgesic effects on mechano-thermal and chemically induced pain. These results confirm the earlier findings that capsaicin is effective for the treatment of neuropathic pain from diabetes, herpes, phantom and stump pain, chronic pain from osteoarthritis, and trigeminal neuralgia.

More recently, the addition of capsaicin has proved effective as a safe topical analgesic by acting as an antiarthritic, antioxidant, and anticancer agent. Capsaicin has also exhibited antiviral properties and effectiveness for the treatment of herpes zoster infection. The Osteoarthritis Research Society International (OARSI) has recommended the topical use of capsaicin as an effective adjunctive or alternative medication to oral analgesics and anti-inflammatory drugs for the treatment of various types of pain (moderate to severe), and to reduce the inflammation in those areas of the body where traditional oral analgesics and anti-inflammatory agents generally do not respond effectively [65].

Another study reported that the carotenoid extract from the dried $C$. annuum induced significant peripheral analgesic activities at the dose values of 5, 20 ad $80 \mathrm{mg} / \mathrm{kg}$, with the dose of $80 \mathrm{mg} / \mathrm{kg}$ registering central analgesia. The synthetic non-pungent capsaicin 
analogs, in particular, the $\mathrm{N}$-acylvanillamides (N-AVAMs), have been studied for the determination of their anticancer and analgesic activities, and various studies have reported their anticancer action against different human cancer cell lines. A capsaicin cream (0.025\%), after topical application, recorded a pain reduction of $57 \%$ and $33 \%$ in patients being treated for osteoarthritis and rheumatoid arthritis [66]. Another study conducted in rats provided conclusive evidence that a nanoemulsion of capsaicin and olive oil (in both the gel and cream formulations) proved effective when compared against a commercially available capsaicin cream both in terms of analgesic activity, as well as the side effect profile [67].

Treatment of pruritus: Chronic pruritus is a condition defined by a persistent itch lasting for more than six weeks, and can be categorized as either generalized (entire skin), or localized (restricted to a particular area, such as the scalp, back, arms, or groin). Capsicum has been found to be an effective treatment remedy for pruritus associated with psoriasis, with a study reporting that 24 hours' treatment of capsaicin was found effective in reducing the perfusion of the skin affected by lesions by $15 \%$, as well as a reduction in (PRP) (characterized by scaling, and redness of the patients' skin), and pruritus to a varying extent [4]. Capsaicin has been shown to act by desensitizing the nerve endings, thereby reducing the conduction of cutaneous itching. Although capsaicin can impart a burning sensation after the first application, this can be overcome by increasing the concentration of Capsicum in the formulation [68].

UTILIZATION IN NONFOOD ITEMS: The chemical extracts from pepper horns (thick-walled chili peppers with the shape of cow horns) have been reported to be effective as an antimicrobial agent against various microorganisms. In a recent study, a nanoemulsion loaded with ethanol extract of pepper horns, and containing various bioactive components, was tested on cotton fabric for the development of medical bandages. The major constituents of the extract included 9,12octadecadienoic (29.99\%), linalyl acetate (18.38\%), Z, Z10,12-hexadecadien-1-ol acetate (14.65\%), and 2methyl-1,5-hexadiene-3-ol (3.75\%). The extract demonstrated superior activity against Gram +ve bacteria and yeast, as compared to the Gram -ve bacteria. The final results also indicated that the cotton fabric treated with low capsicum-based nanoemulsion (2.5\%) had the best antimicrobial properties. Moreover, these properties remained intact even after 10 washing cycles and did not have any discernible effect on the human cell lines [69].

Red chili powder and oleoresins are a rich sources of carotenoid pigments and capsaicinoids. Carotenoids and capsaicinoids which come from the enriched paprika oleoresins have proved an excellent source of color in the cosmetics and pharmaceutical industry, owing to their safety of use, and that their utilization does not require any approvals from regulatory bodies. Paprika oleoresins have found their application in bath oils as well [31]. Water-soluble bioactive compounds such as anthocyanins are also present in capsicum and are used as coloring agents in cosmetics. Furthermore, their use as therapeutic compounds (antioxidants and UV protectors) in the pharmaceutical and cosmetics industry is well documented [70]. The byproducts of Capsicum are now being used in nutricosmetics and cosmeceuticals due to their anti-oxidative and analgesic properties, in the form of oral supplements and topical applications [71, 72]. The detailed uses of capsicum and its byproducts are highlighted in Table 3. 
Table 3: Past few year pieces of research on the utilization of capsicum and its products in the agro-food and cosmetic industry

\begin{tabular}{|c|c|c|c|c|c|}
\hline Type of product & Source & $\begin{array}{l}\text { Associated } \\
\text { bioactive } \\
\text { compound }\end{array}$ & Properties & Uses & Reference \\
\hline $\begin{array}{l}\text { Ground Paprika } \\
\text { powder and } \\
\text { oleoresins }\end{array}$ & $\begin{array}{l}\text { Pungent } \\
\text { paprika }\end{array}$ & $\begin{array}{l}\text { Carotenoids and } \\
\text { capsaicinoids }\end{array}$ & $\begin{array}{l}\text { Coloring and flavoring of } \\
\text { different food items }\end{array}$ & Agro-food industry & [95] \\
\hline Paprika powder & $\begin{array}{l}\text { Red sweet } \\
\text { pepper }\end{array}$ & Carotenoids & $\begin{array}{l}\text { Nitrite replacer, } \\
\text { Help to enhance color, } \\
\text { Prevent lipid oxidation in } \\
\text { pork meat }\end{array}$ & Agro-food industry & {$[96,97]$} \\
\hline Paprika powder & $\begin{array}{l}\text { Red sweet } \\
\text { pepper }\end{array}$ & $\begin{array}{l}\text { Carotenoids and } \\
\text { capsaicinoids }\end{array}$ & $\begin{array}{l}\text { Provide color stability in } \\
\text { meat products, soups, } \\
\text { sauces and snacks }\end{array}$ & Agro-food industry & {$[98,99]$} \\
\hline $\begin{array}{l}\text { Paprika } \\
\text { oleoresin }\end{array}$ & $\begin{array}{l}\text { Sweet } \\
\text { paprika, } \\
\text { pungent } \\
\text { paprika }\end{array}$ & $\begin{array}{l}\text { Carotenoids and } \\
\text { capsaicinoids }\end{array}$ & $\begin{array}{l}\text { Help to enhance the } \\
\text { sensory properties of food }\end{array}$ & Agro-food industry & {$[95,100]$} \\
\hline Pepper flour & $\begin{array}{l}\text { Yellow } \\
\text { pepper }\end{array}$ & Carotenoids & $\begin{array}{l}\text { A major source of } \\
\text { antioxidants, } \\
\text { Help to enhance the } \\
\text { proteins in wheat bread }\end{array}$ & Agro-food industry & [101] \\
\hline $\begin{array}{l}\text { Nanoparticle } \\
\text { paprika oleoresin }\end{array}$ & $\begin{array}{l}\text { Sweet } \\
\text { paprika }\end{array}$ & Carotenoids & $\begin{array}{l}\text { Enhancer of physical and } \\
\text { sensory properties of } \\
\text { cooked marinated chicken }\end{array}$ & Agro-food industry & [102] \\
\hline $\begin{array}{l}\text { Isopropanol } \\
\text { pepper } \\
\text { extraction }\end{array}$ & $\begin{array}{l}\text { Chili } \\
\text { powder }\end{array}$ & Capsaicinoids & $\begin{array}{l}\text { Antimicrobial agent against } \\
\text { S. typhimurium and } P \text {. } \\
\text { aeruginosa in raw beef } \\
\text { meat in combination with } \\
\text { sodium chloride }\end{array}$ & Agro-food industry & [103] \\
\hline $\begin{array}{l}\text { Fractions of } \\
\text { paprika oleoresin }\end{array}$ & $\begin{array}{l}\text { Capsicum } \\
\text { fruits }\end{array}$ & $\begin{array}{l}\text { Carotenoids and } \\
\text { capsaicinoids }\end{array}$ & $\begin{array}{l}\text { Coloring and biological } \\
\text { activities: provitamin A, } \\
\text { antioxidant capacity, } \\
\text { analgesic effect. }\end{array}$ & $\begin{array}{l}\text { Pharmaceutical, } \\
\text { cosmetic and agro- } \\
\text { food industry }\end{array}$ & [104] \\
\hline $\begin{array}{l}\text { Encapsulation of } \\
\text { pepper oleoresin }\end{array}$ & $\begin{array}{l}\text { Chili } \\
\text { pepper }\end{array}$ & $\begin{array}{l}\text { Capsaicinoids and } \\
\text { carotenoids }\end{array}$ & $\begin{array}{l}\begin{array}{l}\text { Enhancer of sensory } \\
\text { properties } \\
\text { emulsions) and biological }\end{array} \\
\text { activities: antimicrobial, } \\
\text { antioxidant and anti- } \\
\text { inflammatory }\end{array}$ & $\begin{array}{l}\text { Pharmaceutical, } \\
\text { cosmetic, and agro- } \\
\text { food industry }\end{array}$ & [105] \\
\hline $\begin{array}{l}\text { Isopropanol } \\
\text { pepper } \\
\text { extraction }\end{array}$ & $\begin{array}{l}\text { Fresh Chili } \\
\text { pepper }\end{array}$ & $\begin{array}{l}\text { Cinnamic acid, o- } \\
\text { coumaric acid, m- } \\
\text { coumaric acid, } \\
\text { ferulic acid and } \\
\text { caffeic acid }\end{array}$ & $\begin{array}{l}\text { Antibacterial activity } \\
\text { against L. Monocytogenes, } \\
\text { B. Cereus, S. Aureus, S. } \\
\text { Typhimurium }\end{array}$ & $\begin{array}{l}\text { Pharmaceutical, } \\
\text { cosmetic and agro- } \\
\text { food industry }\end{array}$ & [106] \\
\hline
\end{tabular}




\begin{tabular}{|c|c|c|c|c|c|}
\hline $\begin{array}{l}\text { Methanol } \\
\text { pepper } \\
\text { extractions }\end{array}$ & $\begin{array}{l}\text { Sweet } \\
\text { pepper }\end{array}$ & $\begin{array}{l}\text { Polyphenols and } \\
\text { carotenoids }\end{array}$ & $\begin{array}{l}\text { Antibacterial activity } \\
\text { against Bacillus cereus and } \\
\text { Escherichia coli and } \\
\text { antifungal activities against } \\
P . \quad \text { expansum and } D . \\
\text { hansenii }\end{array}$ & $\begin{array}{l}\text { Pharmaceutical, } \\
\text { cosmetic, and agro- } \\
\text { food industry }\end{array}$ & [107] \\
\hline $\begin{array}{l}\text { Methanol } \\
\text { pepper } \\
\text { extractions }\end{array}$ & $\begin{array}{l}\text { Sweet } \\
\text { pepper }\end{array}$ & Capsidiol & $\begin{array}{l}\text { Bacteriostatic properties in } \\
\text { vitro against Helicobacter } \\
\text { pylori }\end{array}$ & $\begin{array}{l}\text { Pharmaceutical, } \\
\text { cosmetic, and agro- } \\
\text { food industry }\end{array}$ & [108] \\
\hline $\begin{array}{l}\text { Formulations } \\
\text { ingredients for } \\
\text { topical delivery }\end{array}$ & $\begin{array}{l}\text { Capsicum } \\
\text { fruit }\end{array}$ & $\begin{array}{l}\text { Vitamin C and } \\
\text { carotenoids }\end{array}$ & $\begin{array}{l}\text { Antioxidant and anti- } \\
\text { inflammatory activities, } \\
\text { preventing skin from } \\
\text { oxidative and UVA- } \\
\text { mediated damage }\end{array}$ & $\begin{array}{l}\text { Pharmaceutical and } \\
\text { cosmetic industry }\end{array}$ & [71] \\
\hline $\begin{array}{l}\text { Pepper powder } \\
\text { and oleoresin }\end{array}$ & $\begin{array}{l}\text { Chili } \\
\text { peppers }\end{array}$ & Capsaicin & $\begin{array}{l}\text { The therapeutic agent in } \\
\text { chronic pain syndromes } \\
\text { and chronic inflammatory } \\
\text { skin diseases }\end{array}$ & $\begin{array}{l}\text { Pharmaceutical } \\
\text { industry }\end{array}$ & {$[109,110]$} \\
\hline Pepper powder & $\begin{array}{l}\text { Cayenne } \\
\text { pepper }\end{array}$ & Capsaicinoids & $\begin{array}{l}\text { Pharmacological activities: } \\
\text { alter appetite sensations by } \\
\text { higher satiation }\end{array}$ & $\begin{array}{l}\text { Pharmaceutical } \\
\text { industry }\end{array}$ & {$[111]$} \\
\hline
\end{tabular}

CONCLUSION AND FUTURE TRENDS: During the past few years, the popularity of different varieties of capsicum and their byproducts vehave been increasing. The Capsicum plant contains a vast variety of bioactive compounds and possesses momentous applications across a wide range of domains including food, agriculture, medicine, pharmaceuticals, and cosmetics.

Traditionally, most of the research related to capsicum was focused on the biosynthesis, and characterization of these bioactive constituents, as well as their possible extraction methods using different solvents. However, more recently, the research focus has witnessed a paradigm shift towards the aspect of the utilization of capsicum for a diverse range of applications. In compiling this review article, an attempt has been made to highlight the chemical and functional properties of capsicum.
Capsicum fruit and its associated parts are present as objects of great potential and could be utilized in many industries. The byproducts of this plant have also proven beneficial in the agro-food and textile industry. As the trend is shifting rapidly from synthetic ingredients to natural, the significance and potential of this plant are manifold. Capsicum-derived products such as chili powder, oleoresins, purified extracts, and enriched fractions are widely used due to the presence of capsaicinoids, carotenoids, and polyphenolic compounds. However, there is a need to investigate more into these bioactive components to develop more versatile and healthy food products.

Moreover, to enhance the marketing of these products, their standardization is necessary from the perspective of pungency, color, flavor, and aroma which is currently lacking. There are no harmonized guidelines in the literature for maintaining the 
stability, safety, and quality of capsicum-derived products, in particular, medicinal, food, and cosmetic products. Therefore, more research work is required to establish novel strategies for enhancing extraction efficiency, improving the isolation techniques of bioactive compounds, and expanding the applications of these functional components in several industries.

Competing Interest: The authors declared no conflict of interest.

Abbreviation: LPS, lipopolysaccharides; ROS, Reactive oxygen species; UV, Ultra Violet; BFC,

\section{REFERENCES}

1. Gebhardt, C: The historical role of species from the Solanaceae plant family in genetic research. Theoretical and Applied Genetics 2016, 129(12):2281-2294. https://doi.org/10.1007/s00122-016-2804-1.

2. Kraft, K.H., et al: Multiple lines of evidence for the origin of domesticated chili pepper, Capsicum annuum, in Mexico. Proceedings of the National Academy of Sciences 2014, 111(17): 6165-6170. https://doi.org/10.1073/pnas.1308933111.

3. Carrizo García, C., et al: Phylogenetic relationships, diversification and expansion of chili peppers (Capsicum, Solanaceae). Annals of Botany 2016, 118(1): 35-51. https://doi.org/10.1093/aob/mcw079.

4. Parvez, G.M: Current advances in pharmacological activity and toxic effects of various capsicum species. Int J Pharm Sci Res 2017, 8:1900-1912. doi: 10.13040/IJPSR.0975-8232.8(5).1900-12.

5. Antonio, A., L. Wiedemann, and V.V : The genus Capsicum: a phytochemical review of bioactive secondary metabolites. RSC adv 2018, 8(45): 25767-25784. DOI: 10.1039/C8RA02067A.

6. Di Sotto, A., et al: Capsicum annuum L. var. Cornetto di Pontecorvo PDO: Polyphenolic profile and in vitro biological activities. J Func Foods 2018, 40: 679-691.

https://doi.org/10.1016/j.jff.2017.11.041.
Bioactive Food Components; LOX, Lipoxygenase enzyme; DHC, Dihydrocapsaicin; CVDs, Cardiovascular diseases; SHV, Scoville Heat Value; HVA, Homovanillic acid; ICD, Immunogenic cell death; PRP, pityriasis rubra pilaris; VR, vanilloid receptors; GDM, gestational diabetes mellitus

Author's Contribution: AA: collecting data and compiling the initial draft, WA: table formation and editing, NK: editing and finalizing the draft

Acknowledgment/ Funding: The article was not funded

7. Chapa-Oliver, A.M. and L. Mejía-Teniente: Capsaicin: from plants to a cancer-suppressing agent. Molecule 2016. 21(8): 931. https://doi.org/10.3390/molecules2108093.

8. Zou, Y., et al: Chemical composition and nutritive value of hot pepper seed (Capsicum annuum) grown in Northeast Region of China. J Food Sci Technol 2015, 35(4): 659-663. https://doi.org/10.1590/1678-457X.6803.

9. Kantar, M.B., et al: vitamin variation in Capsicum spp. provides opportunities to improve nutritional value of human diets. PLos One 2016, 11(8): e0161464. https://doi.org/10.1371/journal.pone.0161464.

10. Azam, A., A. Hameed, and I. Khan: Capsicum (Capsicum Annuum). J Mater. Chem 2017.

11. Fathima, S.N: A systemic review on phytochemistry and pharmacological activities of Capsicum annuum. Int J Pharm Pharm Sci 2015, 4(3): 51-68.

12. Imran, M., M.S. Butt, and H.A.R. Suleria: Capsicum annuum bioactive compounds: Health promotion perspectives. Bio Mol Food Cham: Springer 2018: 1-22. DOI: 10.1007/978-3319-78030-6_47.

13. Bartnik, M. and P. Facey, Glycosides, in Pharmacognosy. Elsevier 2017: 101-161.

14. Wahyuni, Y., et al: Metabolite biodiversity in pepper (Capsicum) fruits of thirty-two diverse accessions: Variation in health-related compounds and implications for breeding. 
Phytochem 2011, 72(11-12): 1358-1370. https://doi.org/10.1016/j.phytochem.2011.03.016.

15. de Sá Mendes, N., et al: Characterization of pepper (Capsicum baccatum)-A potential functional ingredient. LWT 2019, 112: 108209. https://doi.org/10.1016/j.lwt.2019.05.107.

16. de Aguiar, A.C., et al: Sequential high-pressure extraction to obtain capsinoids and phenolic compounds from biquinho pepper (Capsicum chinense). J Supercrit Fluids 2019, 150: 112-121. https://doi.org/10.1016/j.supflu.2019.04.01.

17. PADILHA, H.K.M., et al: Genetic variability for synthesis of bioactive compounds in peppers (Capsicum annuum) from Brazil. Food Sci Tech 2015, 35(3): 516-523.

https://doi.org/10.1590/1678-457X.6740.

18. Tsurumaki, K. and T. Sasanuma: Discovery of novel unfunctional pAMT allele pamt10 causing loss of pungency in sweet bell pepper (Capsicum annuum L.). Breed. Sci 2019, 69(1):133-142. https://doi.org/10.1270/jsbbs.18150.

19. Naves, E.R., et al: Capsaicinoids: pungency beyond Capsicum. Trends in Plant Sci 2019, 24(2): 109-120.

https://doi.org/10.1016/j.tplants.2018.11.0.

20. Aza-González, C., H.G. Núñez-Palenius, and N. Ochoa-Alejo: Molecular biology of capsaicinoid biosynthesis in chili pepper (Capsicum spp.). Plant Cell Rep 2011, 30(5): 695-706. https://doi.org/10.1007/s00299-010-0968-8.

21. Basith, S., et al: Harnessing the therapeutic potential of capsaicin and its analogues in pain and other diseases. $\begin{array}{lll}\text { Molecules 2016, } & \text { 21(8): }\end{array}$ https://doi.org/10.3390/molecules2108096.

22. Srinivasan, K: Biological activities of red pepper (Capsicum annuum) and its pungent principle capsaicin: a review. Crit Rev Food Sci Nutr 2016, 56(9): 1488-1500. https://doi.org/10.1080/10408398.2013.77209.

23. Guillen, N.G., R. Tito, and N.G. Mendoza: Capsaicinoids and pungency in Capsicum chinense and Capsicum baccatum fruits1. Pesqui Agropecu Trop 2018, 48: 237-244. https://doi.org/10.1590/1983-40632018v4852334.

24. Tremblay, A., H. Arguin, and S. Panahi: Capsaicinoids: a spicy solution to the management of obesity? Int J Obes 2016, 40(8):1198-1204. https://doi.org/10.1038/ijo.2015.253.

25. Arce-Rodríguez, M.L. and N. Ochoa-Alejo: Biochemistry and molecular biology of capsaicinoid biosynthesis: recent advances and perspectives. Plant Cell Rep 2019: 1-14. https://doi.org/10.1007/s00299-019-02406-0.
26. Mamedov, M., et al: Antioxidant contents of pepper Capsicum spp. for use in biofortification. Sel'skokhozyaistvennaya biologiya [Agricultural Biology] 2017, 52: 5. doi:

10.15389/agrobiology.2017.5.1021rus.

27. Arimboor, R., et al: Red pepper (Capsicum annuum) carotenoids as a source of natural food colors: analysis and stability-a review. J Food Sci Technol 2015, 52(3): 12581271. https://doi.org/10.1007/s13197-014-1260-7.

28. Mohd Hassan, N., et al: Carotenoids of Capsicum Fruits: Pigment Profile and Health-Promoting Functional Attributes. Antioxidants 2019, 8(10): 469.

https://doi.org/10.3390/antiox8100469.

29. Kim, J.-S., et al: Carotenoid profiling from 27 types of paprika (Capsicum annuum L.) with different colors, shapes, and cultivation methods. Food Chem 2016, 201: 64-71. https://doi.org/10.1016/j.foodchem.2016.01.01.

30. Shakeri, A., et al: Biological activities of three natural plant pigments and their health benefits. J FOOD MEAS CHARACT 2018, 12(1): 356-361. doi:10.1007/s11694-017-9647-6.

31. Baenas, N., et al: Industrial use of pepper (Capsicum annum L.) derived products: Technological benefits and biological advantages. Food Chem 2019, 274: 872-885. https://doi.org/10.1016/j.foodchem.2018.09.047.

32. Lara-Hidalgo, C., et al: Contribution of autochthonous yeasts with probiotic potential to the aroma profile of fermented Guajillo pepper sauce. J Sci Food Agri 2020, 100(13): 49404949. https://doi.org/10.1002/jsfa.10556.

33. Cirlini, M., et al: Evaluation of the volatile fraction, pungency and extractable color of different Italian Capsicum annuum cultivars designed for food industry. Eur Food Res Technol 2019, 245(12): 2669-2678. https://doi.org/10.1007/s00217-019-03378-x.

34. Garruti, D.d.S., et al: Volatile profile and sensory quality of new varieties of Capsicum chinense pepper. Food Sci Technol 2013, 33:102-108. DOI : 10.1590/S010120612013000500016.

35. Kollmannsberger, H., Rodríguez-Burruezo, A., Nitz, S., andNuez, F: Volatile and capsaicinoid composition of ají (Capsicum baccatum) and rocoto (Capsicum pubescens), two Andean species of chile peppers. J Sci Food Agri 2011, 91(9): 1598-1611.

https://doi.org/10.1002/jsfa.4354. 
36. Morales-Soriano, E., et al., Flavor characterization of native Peruvian chili peppers through integrated aroma fingerprinting and pungency profiling. Food Res Int 2018, 109: 250-259. https://doi.org/10.1016/j.foodres.2018.04.030.

37. Rodríguez-Burruezo, A., et al., HS-SPME comparative analysis of genotypic diversity in the volatile fraction and aromacontributing compounds of Capsicum fruits from the Annuum- Chinense- Frutescens complex. J Agric Food Chem 2010, 58(7): 4388-4400. https://doi.org/10.1021/jf903931t.

38. Zhang, Q., et al: Physicochemical, microbial, and aroma characteristics of Chinese pickled red peppers (Capsicum annuum) with and without biofilm. Rsc Adv 2020, 10(11): 6609-6617. DOI: 10.1039/DORA00490A.

39. Singletary, K: Red pepper: overview of potential health benefits. Nutr Today 2011, 46(1): 33-47. doi: 10.1097/NT.0b013e3182076ff2.

40. Pawar, S., et al: Chillies as food, spice and medicine: a perspective. Int J Pharm Bio Sci 2011, 1(3): 311-318.

41. Maji, A.K. and P. Banerji: Phytochemistry and gastrointestinal benefits of the medicinal spice, Capsicum annuum L.(Chilli): a review. J Complement Integr Med 2016, 13(2): 97-122. https://doi.org/10.1515/jcim-2015-0037.

42. Dog, T.L: A reason to season: the therapeutic benefits of spices and culinary herbs. Explore J Sci Heal 2006, 2(5): 446 449.

43. Kim, W.-R., et al: Antioxidant activity of phenolics in leaves of three red pepper (Capsicum annuum) cultivars. J Agric Food Chem 2014, 62(4): 850-859. https://doi.org/10.1021/jf403006c.

44. El-Ghorab, A., et al: Pakistani bell pepper (Capsicum annum L.): chemical compositions and its antioxidant activity. Int J Food Propr 2013, 16(1): 18-32. https://doi.org/10.1080/10942912.2010.513616.

45. Melgar-Lalanne, G., et al., Oleoresins from Capsicum spp.: Extraction Methods and Bioactivity. Food Bioproc Tech 2017, 10(1): 51-76. doi:10.1007/s11947-016-1793-z.

46. Škrovánková, S., et al: Polyphenols content and antioxidant activity of paprika and pepper spices. Potravinarstvo 2017. doi:

https://dx.doi.org/10.5219/695.

47. Mokhtar, M., et al: Antimicrobial activity of selected polyphenols and capsaicinoids identified in pepper (Capsicum annuum L.) and their possible mode of interaction. Current Micro 2017, 74(11): 1253-1260.

https://doi.org/10.1007/s00284-017-1310-2.

48. Anikwe, L., et al: Antimicrobial activities of four varieties of Capsicum annuum fruits cultivated in Southeast Nigeria against multidrug-resistant and susceptible organisms. Basic Clin Pharmacol Toxicol 2017, 1(2): 21-26. http://www.scigreen.com/index.php/JBPT/article/view/21.

49. Yamasaki, S., et al: Inhibition of virulence potential of Vibrio cholerae by natural compounds. Indian J Med Res 2011, 133(2): 232.

50. Gurnani, N., et al: Chemical composition, total phenolic and flavonoid contents, and in vitro antimicrobial and antioxidant activities of crude extracts from red chilli seeds (Capsicum frutescens L.). J Taibah Univ Sci 2016, 10(4): 462-470. https://doi.org/10.1016/j.jtusci.2015.06.011.

51. Gayathri, N., M. Gopalakrishnan, and T. Sekar: Phytochemical screening and antimicrobial activity of Capsicum chinense Jacq. Int J Adv Pharm 2016, 5(1):12-20. DOI: 10.7439/ijap.

52. Bakht, J., et al: Antimicrobial activity of different solvent extracted samples from the leaves and fruits of Capsicum annuum. Pak J Pharm Sci 2020, 33(1).

53. Della Badia, A., A.A. Spina, and G. Vassalotti, Capsicum annuum L.: An Overview of Biological Activities and Potential Nutraceutical Properties in Humans and Animals. 2017. doi:10.1166/jnef.2017.1163

54. Laohavechvanich, P., et al: Effect of different Thai traditional processing of various hot chili peppers on urethane-induced somatic mutation and recombination in Drosophila melanogaster: Assessment of the role of glutathione transferase activity. Food Chem Toxicol 2006, 44(8): 13481354. https://doi.org/10.1016/j.fct.2006.02.013.

55. Jin, T., et al: Capsaicin induces immunogenic cell death in human osteosarcoma cells. Exp Ther Med 2016, 12(2): 765770.

https://doi.org/10.3892/etm.2016.3368.

56. Lin, M.-H., et al: Capsaicin inhibits multiple bladder cancer cell phenotypes by inhibiting tumor-associated NADH oxidase (tNOX) and sirtuin1 (SIRT1). Molecules 2016, 21(7): 849. https://doi.org/10.3390/molecules21070849.

57. Friedman, J.R., et al: Capsaicinoids: Multiple effects on angiogenesis, invasion and metastasis in human cancers. 
Biomed Pharmacother 2019, 118:109317 https://doi.org/10.1016/j.biopha.2019.109317.

58. Yuan, L.-J., et al: Capsaicin-containing chili improved postprandial hyperglycemia, hyperinsulinemia, and fasting lipid disorders in women with gestational diabetes mellitus and lowered the incidence of large-for-gestational-age newborns. Clin Nutr 2016, 35(2): 388-393. https://doi.org/10.1016/j.clnu.2015.02.011.

59. Hong, Z.-F., et al: Capsaicin Enhances the Drug Sensitivity of Cholangiocarcinoma through the Inhibition of Chemotherapeutic-Induced Autophagy. PLOS ONE, 2015, 10(5): e0121538. doi:10.1371/journal.pone.0121538.

60. Hu, Y.-W., et al: Dihydrocapsaicin attenuates plaque formation through a PPARY/LXR $\alpha$ pathway in apoe-/- mice fed a high-fat/high-cholesterol diet. PLoS One 2013, 8(6) : e66876-e66876. doi:10.1371/journal.pone.0066876.

61. Sanati, S., B.M. Razavi, and H. Hosseinzadeh: A review of the effects of Capsicum annuum L. and its constituent, capsaicin, in metabolic syndrome. Iran J Basic Med Sci 2018, 21(5): 439. doi: 10.22038/IJBMS.2018.25200.6238.

62. Bhattacharya, A., et al: Antioxidant constituents and enzyme activities in chilli peppers. Int J Veg Sci 2010, 16(3): 201-211. https://doi.org/10.1080/19315260903529709.

63. Luo, X.-J., J. Peng, and Y.-J. Li: Recent advances in the study on capsaicinoids and capsinoids. Eurp J Pharm 201, 650(1):17.

https://doi.org/10.1016/j.ejphar.2010.09.074.

64. Jolayemi, A. and J. Ojewole: Comparative anti-inflammatory properties of Capsaicin and ethylaAcetate extract of Capsicum frutescens linn [Solanaceae] in rats. Afr Healt Sci 2013, 13(2): 357-361. DOI: 10.4314/ahs.v13i2.23

65. Rudrapal, M. and K.K. Sarwa, Capsicum: Chemistry and Medicinal Properties of Indigenous Indian Varieties, in Capsicum. IntechOpen 2020.

66. Batiha, G.E.-S., et al: Biological Properties, Bioactive Constituents, and Pharmacokinetics of Some Capsicum spp. and Capsaicinoids. Int J Mol Sci 2020, 21(15): 5179. https://doi.org/10.3390/ijms21155179.

67. Hall, O.M., et al: Novel Agents in Neuropathic Pain, the Role of Capsaicin: Pharmacology, Efficacy, Side Effects, Different Preparations. Curr Pain Headache Rep 2020, 24(9): 1-12. https://doi.org/10.1007/s11916-020-00886-4.
68. Karim, K: Diagnosis, treatment and management of pruritus. $\mathrm{Br} J$ Nurs 2011, 20(6): 356-361. https://doi.org/10.12968/bjon.2011.20.6.356.

69. El-Naggar, M.E., et al: Nanoemulsion of Capsicum fruit extract as an eco-friendly antimicrobial agent for production of medical bandages. Biocatal Agric Biotechnol 2020, 23: 101516. https://doi.org/10.1016/j.bcab.2020.101516.

70. El Ksibi, l., et al: Mixture approach for optimizing the recovery of colored phenolics from red pepper (Capsicum annum L.) by-products as potential source of natural dye and assessment of its antimicrobial activity. Ind Crops Prod 2015, 70: 34-40.

https://doi.org/10.1016/j.indcrop.2015.03.017.

71. Telang, P.S: Vitamin C in dermatology. Indian Dermatol Online J 2013, 4(2): 143. doi: 10.4103/2229-5178.110593.

72. Palombo, P., et al: Beneficial long-term effects of combined oral/topical antioxidant treatment with the carotenoids lutein and zeaxanthin on human skin: a double-blind, placebo-controlled study. Skin Pharmacol Physiol 2007, 20(4): 199-210. https://doi.org/10.1159/000101807.

73. Sharma, J., P. Sharma, and B. Chaudhary, Estimation of Proximate Composition of Selected Species of Capsicum (Capsicum annuum and Capsicum chinense) Grown in India. Inter J of Pure and Appl Biosci 2017, 5(3): 369-372.

74. Qian, K., et al: Capsaicin suppresses cell proliferation, induces cell cycle arrest and ROS production in bladder cancer cells through FOXO3a-mediated pathways. Molecules 2016, 21(10): 1406.

https://doi.org/10.3390/molecules21101406.

75. Vendrely, V., et al: Resveratrol and capsaicin used together as food complements reduce tumor growth and rescue full efficiency of low dose gemcitabine in a pancreatic cancer model. Cancer Lett 2017, 390: 91-102. https://doi.org/10.1016/j.canlet.2017.01.002.

76. Wang, F., et al: Capsaicin reactivates hMOF in gastric cancer cells and induces cell growth inhibition. Cancer Biol Ther 2016, 17(11): 1117-1125. https://doi.org/10.1080/15384047.2016.1235654.

77. Bessler, H. and M. Djaldetti: Capsaicin modulates the immune cross talk between human mononuclears and cells from two colon carcinoma lines. Nutr Cancer 2017, 69(1):14-20. https://doi.org/10.1080/01635581.2017.1247893. 
78. Amantini, C., et al: Capsaicin triggers autophagic cell surviva which drives epithelial mesenchymal transition and chemoresistance in bladder cancer cells in an Hedgehogdependent manner. Oncotarget 2016, 7(31): 50180. doi: 10.18632/oncotarget.10326.

79. Liu, T., et al: Capsaicin mediates caspases activation and induces apoptosis through P38 and JNK MAPK pathways in human renal carcinoma. BMC cancer 2016, 16(1): 790 https://doi.org/10.1186/s12885-016-2831-y.

80. Chen, J., et al: Activation of TRPV1 channel by dietary capsaicin improves visceral fat remodeling through connexin43-mediated Ca 2+ influx. Cardiovasc Diabetol 2015. 14(1): 22. https://doi.org/10.1186/s12933-015-0183-6.

81. Hu, Y.-W., et al: Dihydrocapsaicin Attenuates Plaque Formation through a PPARY/LXR $\alpha$ Pathway in apoE(-/-) Mice Fed a High-Fat/High-Cholesterol Diet. PloS one 2013, 8(6): e66876-e66876. doi:10.1371/journal.pone.0066876.

82. McCarty, M., J. DiNicolantonio, and J. O'Keefe: Capsaicin may have important potential for promoting vascular and metabolic health. Open Heart, 2: e000262. 2015.

http://dx.doi.org/10.1136/openhrt-2015-000262.

83. Duzhyy, D.E., et al., Upregulation of T-type Ca2+ channels in long-term diabetes determines increased excitability of a specific type of capsaicin-insensitive DRG neurons. Mol pain 2015, 11: s12990-015-0028-z. https://doi.org/10.1186/s12990-015-0028-z.

84. Skrzypski, M., et al: Capsaicin induces cytotoxicity in pancreatic neuroendocrine tumor cells via mitochondrial action. Cell Signal 2014, 26(1): 41-48.

https://doi.org/10.1016/j.cellsig.2013.09.014.

85. Kang, J.-H., et al: Dietary capsaicin attenuates metabolic dysregulation in genetically obese diabetic mice. J Med Food 201, 14(3): 310-315. https://doi.org/10.1089/jmf.2010.1367.

86. Baskaran, P., et al: Capsaicin induces browning of white adipose tissue and counters obesity by activating TRPV1 channel-dependent mechanisms. Bri J Pharm 2016, 173(15) 2369-2389. https://doi.org/10.1111/bph.13514.

87. Ibrahim, M., et al: Capsaicin inhibits the adipogenic differentiation of bone marrow mesenchymal stem cells by regulating cell proliferation, apoptosis, oxidative and nitrosative stress. Food Func 2015, 6(7): 2165-2178 https://doi.org/10.1039/C4FO01069H.
88. Pyun, C.W., et al: In vivo protective effects of dietary curcumin and capsaicin against alcohol-induced oxidative stress. Biofact 2014, 40(5): 494-500. https://doi.org/10.1002/biof.1172.

89. Lee, T.-H., et al: Capsaicin prevents kainic acid-induced epileptogenesis in mice. Neurchem Int 2011, 58(6): 634-640. https://doi.org/10.1016/j.neuint.2011.01.027.

90. Persson, M.S., et al: Relative efficacy of topical non-steroidal anti-inflammatory drugs and topical capsaicin in osteoarthritis: protocol for an individual patient data metaanalysis. Syst Rev 2016, 5(1):165. https://doi.org/10.1186/s13643-016-0348-8.

91. Walker, J., et al: Nonivamide, a capsaicin analogue, exhibits anti-inflammatory properties in peripheral blood mononuclear cells and U-937 macrophages. Mol Nutr Food Res 2017, 61(2): 1600474.

https://doi.org/10.1002/mnfr.201600474.

92. Jung, H.J., et al: Antiangiogenic activity of the lipophilic antimicrobial peptides from an endophytic bacterial strain isolated from red pepper leaf. Mol Cells 2015, 38(3): 273. doi: 10.14348/molcells.2015.2320.

93. Leung, F.W: Capsaicin as an anti-obesity drug, in Capsaicin as a therapeutic molecule. 2014, Springer. p. 171-179.

94. PARLE, M. and S. KAURA, Green chilli: A memory booster from nature. Ann. Pharm. and Pharm. Sci.,4 (1 and 2): 17-21

95. Tepić, A.N., et al: Quality of commercial ground paprika and its oleoresins. Acta Periodic Tech 2008, (39): 77-83. DOI: 10.2298/AРT0839077T.

96. Bázan-Lugo, E: Color compensation in nitrite-reduced meat batters incorporating paprika or tomato paste. J Sci Food Agric 2012, 92(8):1627-1632.

https://doi.org/10.1002/jsfa.4748.

97. Martínez, L., et al: Effect of Capsicum annuum (red sweet and cayenne) and Piper nigrum (black and white) pepper powders on the shelf life of fresh pork sausages packaged in modified atmosphere. J Food Sci 2006, 71(1): S48-S53. https://doi.org/10.1111/j.1365-2621.2006.tb12405.x

98. Fernández-López, J., et al: Effect of paprika (Capsicum annum) on color of Spanish-type sausages during the resting stage. J Food Sci 2002, 67(6): 2410-2414. https://doi.org/10.1111/j.1365-2621.2002.tb09562.x.

99. Pruthi, J: Chemistry and quality control of Capsicums and Capsicum products, in Capsicum. CRC Press 2003, 45-90. 
100. Uquiche, E., J.M. del Valle, and J. Ortiz: Supercritical carbon dioxide extraction of red pepper (Capsicum annuum L.) oleoresin. J Food Eng 2004, 65(1): 55-66 https://doi.org/10.1016/j.jfoodeng.2003.12.003.

101. Danza, A., et al: Processing and characterization of durum wheat bread enriched with antioxidant from yellow pepper flour. LWT-Food Sci Tech 2014, 59(1): 479-485. https://doi.org/10.1016/j.lwt.2014.06.001.

102. Yusop, S.M., et al: Assessment of nanoparticle paprika oleoresin on marinating performance and sensory acceptance of poultry meat. LWT-Food Sci Tech, 2012. 46(1): 349-355. https://doi.org/10.1016/j.lwt.2011.08.014.

103. Careaga, M., et al: Antibacterial activity of Capsicum extract against Salmonella typhimurium and Pseudomonas aeruginosa inoculated in raw beef meat. International J Food Micro 2003, 83(3): 331-335. https://doi.org/10.1016/S01681605(02)00382-3.

104. Fernández-Ronco, M.P: New considerations in the economic evaluation of supercritical processes: separation of bioactive compounds from multicomponent mixtures. J Superctc Fluids 2013, 79: 345-355.

https://doi.org/10.1016/j.supflu.2013.01.018.

105. De Aguiar, A.C: Encapsulation of pepper oleoresin by supercritical fluid extraction of emulsions. J SupercriticFluids 2016, 112: 37-43. https://doi.org/10.1016/j.supflu.2016.02.009.

106. Dorantes, L., et al: Inhibition of growth of some foodborne pathogenic bacteria by Capsicum annum extracts. Int J Food Micro 2000, 57(1-2): 125-128. https://doi.org/10.1016/S0168-1605(00)00216-6.

107. Nazzaro, F., et al: Comparative content of some bioactive compounds in two varieties of Capsicum annuum L. sweet pepper and evaluation of their antimicrobial and mutagenic activities. J Food Biochem 2009, 33(6): 852-868. https://doi.org/10.1111/j.1745-4514.2009.00259.x.

108. De Marino, S., et al: New constituents of sweet Capsicum annuum L. fruits and evaluation of their biological activity. J Agric Food Chem 2006, 54(20): 7508-7516. https://doi.org/10.1021/jf061404z.

109. CĂRUNTU, C., et al: Capsaicin, a hot topic in skin pharmacology and physiology. Inflammation 2015, 8(40): 21.

110. Lysy, J., et al: Topical capsaicin-a novel and effective treatment for idiopathic intractable pruritus ani: a randomised, placebo controlled, crossover study. Gut 2003, 52(9): 1323-1326. http://dx.doi.org/10.1136/gut.52.9.1323.

111. Andersen, B., et al: Cayenne pepper in a meal: Effect of oral heat on feelings of appetite, sensory specific desires and wellbeing. Food Qual Prefer 2017, 60: 1-8. https://doi.org/10.1016/j.foodqual.2017.03.007. 